Available online at GSC Online Press Directory

GSC Advanced Research and Reviews e-ISSN: 2582-4597, CODEN (USA): GARRC2

Journal homepage: https://www.gsconlinepress.com/journals/gscarr

(RESEARCH ARTICLE)

\title{
Anticholinergic and adrenergic activities of a dichloromethane fraction of a crude ethanol extract of stem bark of Piliostigma reticulatum Horscht D.C (Ceasalpiniaceae)
}

\author{
Dosso Kassim 1, ${ }^{*}$, Attemene Dago Serge David ${ }^{1}$, Gboko Abiba Ouattara ${ }^{2}$, N'guessan Benoit Banga ${ }^{3}$, and \\ Yapo Angoue Paul 4 \\ ${ }^{1}$ Laboratory of Physiology and Pharmacology, faculty of Environment, University of Jean Lorougnon Guede of Daloa, 02 \\ P.O Box 150 Daloa 02, Côte d'Ivoire. \\ ${ }^{2}$ Laboratory of Biotechnology in agro-resources valorization and natural substances, UFR Biological Sciences, University \\ of Korhogo, P.O Box 1328 Korhogo, Korhogo, Côte d'Ivoire. \\ ${ }^{3}$ Department of Pharmacology and Toxicology, School of Pharmacy, College of Health Sciences, University of Ghana, P.O \\ Box KB 52, Korle-Bu, Accra, Ghana. \\ ${ }^{4}$ Laboratory of Physiology and Pharmacology, faculty of Natural Sciences, University of Nangui Abrogoua, 01 P.O Box 801 \\ Abidjan 01, Côte d'Ivoire.
}

Publication history: Received on 22 February 2020; accepted on 07 April 2020

Article DOI: https://doi.org/10.30574/gscarr.2020.3.1.0012

\begin{abstract}
The objective of the present study was to investigate the anticholinergic and adrenergic activities of a dichloromethane fraction of a crude ethanol extract of stem bark of $P$. reticulatum, on isolated rabbit duodenum contractions. In the first study, the dichloromethane fraction was tested on the isolated rabbit duodenum contractions at increasing concentrations $(0.13 ; 0.26 ; 0.39$ and $0.52 \mathrm{mg} / \mathrm{mL})$ after addition of acetylcholine. In the second study, the dichloromethane fraction was tested on the isolated rabbit duodenum contractions ten minutes after addition of prazosin or propanolol at increasing concentrations $\left(10^{-4}, 10^{-3}\right.$ and $\left.10^{-2} \mathrm{mg} / \mathrm{mL}\right)$. The amplitude and tone induced by acetylcholine were significantly inhibited by the dichloromethane fraction. At a concentration of $0.52 \mathrm{mg} / \mathrm{mL}$, the amplitude induced by the acetylcholine was $0.42 \pm 0.05 \mathrm{~g}$. The relaxation induced by the dichloromethane fraction was significantly inhibited by prazosin and propanolol as well. At a concentration of $10^{-2} \mathrm{mg} / \mathrm{mL}$, prazosin and propanolol inhibited the relaxation induced by the dichloromethane fraction at rates of $18.6 \pm 2.42$ and $17.4 \pm 0.7 \%$ respectively. Results showed that the dichloromethane fraction of crude ethanol extract of stem bark of Piliostigma reticulatum exhibited anticholinergic and adrenergic properties that could at least explain and back up its traditional use against diarrhea.
\end{abstract}

Keywords: Acetylcholine; Diarrhea; Piliostigma reticulatum; Prazosin; Propranolol.

\section{Introduction}

Today the treatment of spastic motility disorders is a real concern. Therapeutic options remain limited on account of our failure to understand pathophysiology and its significance [1]. Drugs are used against hyper-contractility of smooth muscles and allow the gastrointestinal muscle to return to their proper tone [2]. Antispasmodic drugs include antimuscarinic compounds (e.g. Alkaloids derived from belladonna and their synthetic derivatives) and calcium channel blockers (e.g. otilonium and pinaverium) are the principal modern drugs used by population to treat gastrointestinal disorders $[3,4]$. These drugs in addition to their pharmacological effects are responsible of some adverse effects in the organism.

\footnotetext{
* Corresponding author: Dosso Kassim kassdoss02@yahoo.fr / +22549935642
} 
Thus, some medicinal plant species are used in traditional medicine by rural populations for the treatment of gastrointestinal disorders including diarrhea, indigestion and constipation [5, 6, 7]. In order to determine the mechanism of these plants in the treatment of gastro-intestinal disorders, scientists use essentially the antagonism study on the intestine contraction with chemicals products like acetylcholine, prazosin and propranolol. Studies carried on some isolated organs demonstrate that some medicinal plant species have anticholinergic or adrenergic effect $[8,9$, $10]$.

Piliostigma reticulatum used in this study, is found in the tropical forests of west african countries like Côte d'Ivoire, Mali and Burkina Faso and is traditionally used against ailments such as ulcers [11], boils, wounds, syphilitic cancer [12, $13]$ and diarrhea $[12,14,15]$. In our previous studies, before toxicity study [16], the dichloromethane fraction showed an activity against diarrhea [17], electrolytes secretion [18] and bacterial diarrhea [19]. The effects of Piliostigma reticulatum are studied on biochemical parameters in rats [20]. Therefore, the mechanism of the spasmodic property of this plant has not yet been investigated to our knowledge. The present work was designed to assess the anticholinergic and adrenergic effects of the dichloromethane fraction on contractions of smooth muscle of an isolated rabbit duodenum.

\section{Material and methods}

\subsection{Plant material}

Stem barks of Piliostigma reticulatum (DC.) Horscht (Ceasalpiniaceae) were collected in Abidjan (South region of Côte d'Ivoire). The plant was identified and authenticated by the National Centre of Floristic of the University of Félix Houphouet Boigny-Abidjan by Pr AKE ASSI. A voucher specimen ( $\left.N^{\circ} 18033\right)$ of the plant was deposited in the herbarium of the National Centre of Floristic of the University of Félix Houphouet Boigny- Abidjan.

\subsection{Preparation of the ethanol extract and dichloromethane fraction}

Stem barks of Piliostigma reticulatum were washed with distilled water, cleaned, cut into small pieces and kept at room temperature for two weeks. Then, they were ground into a fine powder. The powder (100 g) was suspended in 2 liters of a solution of ethanol (96\%) / water (80:20) for 24 hours under constant stirring (this operation was repeated twice). The extract was filtered twice through cotton wool, then through Whattman filter paper $\left(\mathrm{N}^{\circ} 1\right)$. The filtrate was evaporated to dryness using a rotavapor (Buchi R110/NKE6540/2), and dried under reduced pressure. Five liquid fractions (heptane, dichloromethane, ethyl acetate, butanol and aqueous) were obtained from the crude ethanol extract by using successive liquid-liquid extraction [21,22]. The dichloromethane fraction was used because of its efficiency in preliminary studies compared to the others.

\subsection{Animals}

Healthy rabbits (weighing 1.5-2 kg) provided by the faculty of Biosciences (University of Félix Houphouet boigny Abidjan, Côte d'Ivoire) were used. They were kept and maintained under standard laboratory conditions one week prior to experiments. Animals were fed with food pellet (Ivograin ${ }^{\circledR}$, Abidjan, Côte d'Ivoire) and were given water ad libitum. They were deprived from food and for at least $24 \mathrm{~h}$ prior to experiments.

Experiments were carried out in accordance with the European Council legislation 87/609/EEC for the protection of experimental animals [23].

\subsection{Smooth muscle preparation}

The experiments were carried out according to the general technique of Magnus [24]. The animals were killed by median laparotomy and the duodenum was removed. Two (2) $\mathrm{cm}$ long of the duodenum segment was suspended in $150 \mathrm{~mL}$ organ bath containing Tyrode's solution of the following composition (mM): $\mathrm{NaCl} 136.89, \mathrm{KCl} 2.68, \mathrm{CaCl}_{2} 1.80, \mathrm{MgCl}_{2}$ $1.05, \mathrm{NaHCO}_{3} 11.90, \mathrm{NaHPO}_{4} 0.42$ and glucose 5.55 , maintained at $37{ }^{\circ} \mathrm{C}$. The solution was aerated with a mixture of $95 \% \mathrm{O}_{2}$ and $5 \% \mathrm{CO}_{2}$.under a resting tension of $1 \mathrm{~g}$. The preparations were connected to a transducer coupled to the paper graph. The suspended duodenum was allowed to equilibrate for $30 \mathrm{~min}$. The smooth muscles relaxant action of test materials was observed by administration of extracts [25]. The bath was washed after testing each concentration of the extract.

The inhibition of duodenum contraction by test sample was expressed as mean percentage \pm SEM from six experiments in the presence of the extract and was calculated using the following formula: 
Dosso et al. / GSC Advanced Research and Reviews, 2020, 03(01), 001-010

$$
\% \text { Inhibition }=\frac{A-B}{A} \times 100
$$

Where $\mathrm{A}$ is the amplitude $(\mathrm{cm})$ of the normal duodenum contraction and B the amplitude $(\mathrm{cm})$ of the duodenum contraction induced by the extract in the presence of the test sample [26].

\subsection{Study of antagonism}

For the antagonism between acetylcholine and the dichloromethane fraction, $7.0910^{-4} \mathrm{mg} / \mathrm{mL}$ of acetylcholine were tested on intestine contraction. This concentration of acetylcholine was the $\mathrm{IC}_{50}$, obtained after the dose-response study. The concentrations of $0.13 ; 0.26 ; 0.39$ and $0.52 \mathrm{mg} / \mathrm{mL}$ were successively tested just after the acetylcholine effect on intestine contraction [27]. Prazosin and propanolol were tested on intestine contraction at concentrations of $10^{-4}, 10^{-3}$ and $10^{-2} \mathrm{mg} / \mathrm{mL}$. The concentration of $0.24 \mathrm{mg} / \mathrm{mL}$ of dichloromethane fraction which was the IC $\mathrm{C}_{50}$ after the doseresponse study was tested 10 minutes after prazosin or propanolol effect on the intestine contraction [28].

\subsection{Source of chemical products}

Acetylcholine, prazosin and propanolol were collected from SIGMA (St. Louis, MO, USA).

\subsection{Phytochemical screening}

The dichloromethane fraction was screened for the presence of tannins, flavonoids, alkaloids, sterols, saponins, polyphenols, polyterpenes and quinons. Detection of these phytocompounds was performed as described by [29].

\subsection{Statistical analysis}

The results were expressed as mean \pm SEM. Data were analyzed for statistical significance by one-way ANOVA followed by Tukey post-hoc test using the software GraphPad prism (San Diego) 5. p $<0.05$ was considered as statistically significant.

\section{Results}

\subsection{Extraction of plant material}

The amount of total ethanol extract was $13.6 \%$. From a dried total ethanol extract (10 g), we successively obtained heptane fraction ( $90 \mathrm{mg} ; 3.6 \%$ ), dichloromethane fraction (200 mg; 8\%), ethyl acetate fraction (500 mg; 20\%), butanol fraction (700 mg; 28\%) and aqueous fraction (900 mg; 36\%).

\subsection{Anticholinergic activity of dichloromethane fraction}

The introduction of dichloromethane fraction at concentrations of $0.13 ; 0.26 ; 0.39$ and $0.52 \mathrm{mg} / \mathrm{mL}$ provoked the inhibition of amplitude and tone induced by acetylcholine (figure 1).

Decrease of contraction amplitude induced by acetylcholine was significant $(\mathrm{p}<0.01$ ) and were $4.7 \pm 2.2 ; 3.3 \pm 1.9 ; 1.12$ \pm 0.8 and $0.42 \pm 0.05 \mathrm{~g}$ respectively at concentrations of $0.13 ; 0.26 ; 0.39$ and $0.52 \mathrm{mg} / \mathrm{mL}$ for dichloromethane fraction (figure 2). The dichloromethane fraction significantly decreased $(\mathrm{p}<0.01)$ the tone induced by acetylcholine to $0.08 \pm$ $0.01 \mathrm{~g}$ at the concentration of $0.52 \mathrm{mg} / \mathrm{mL}$ (figure 3 ). 
A control WAMAMHAMBD
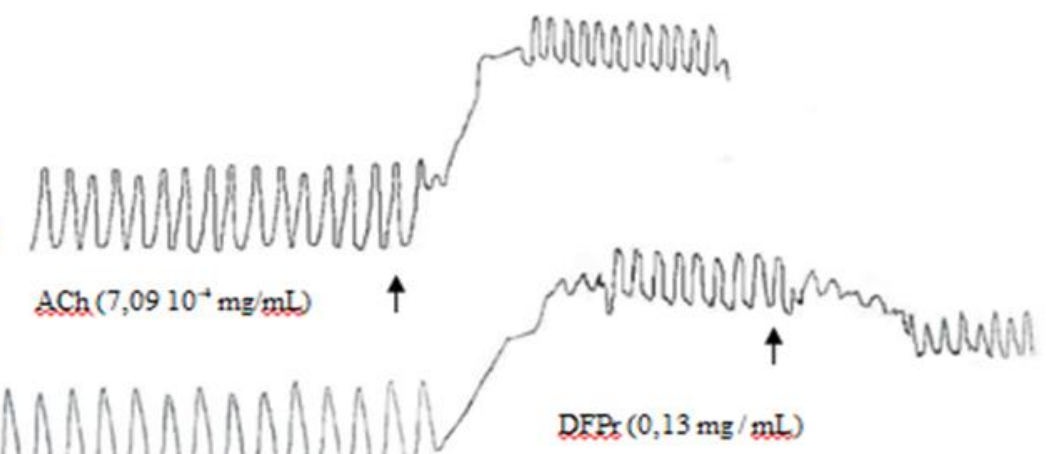

B

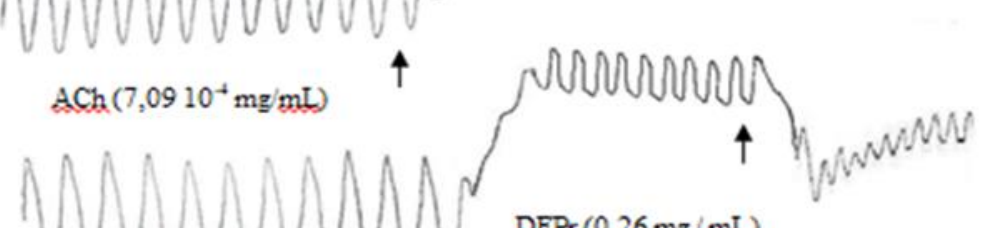

C

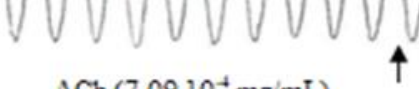

$\operatorname{DFR}(0,26 \mathrm{mg} / \mathrm{mL})$

D
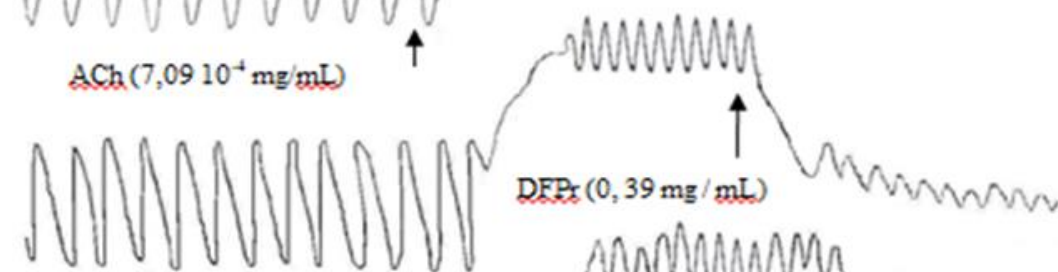

DVVVVVVVVV

$\operatorname{DFR}(0,39 \mathrm{mg} / \mathrm{mL})$
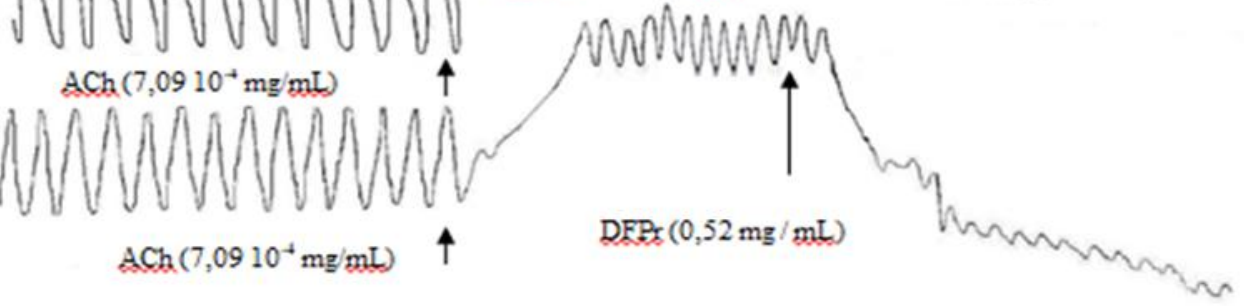

Figure 1 Interaction ACh-Dichloromethane fraction (DFPr) on contractions of isolated rabbit duodenum $(\mathrm{n}=6)$.

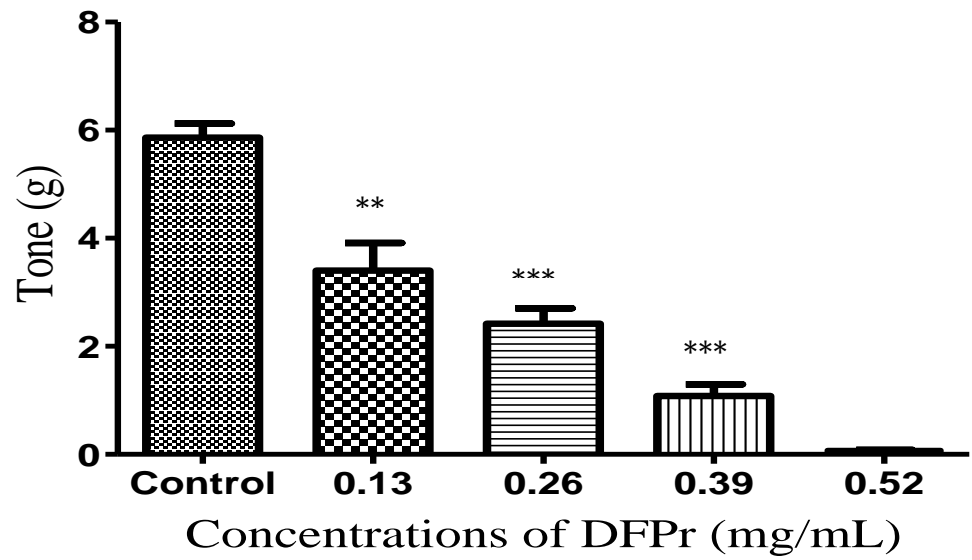

Figure 2 Decrease of the amplitude of intestine contractions induced by ACh in presence of $\operatorname{DFPr}\left({ }^{* *} \mathrm{P}<0.01\right.$; ${ }^{* * *} \mathrm{P}<0$. 001; $\mathrm{n}=6)$.

DFPr $=$ Dichloromethane fraction of Piliostigma reticulatum

$$
\mathrm{ACh}=\text { Acetylcholine }
$$




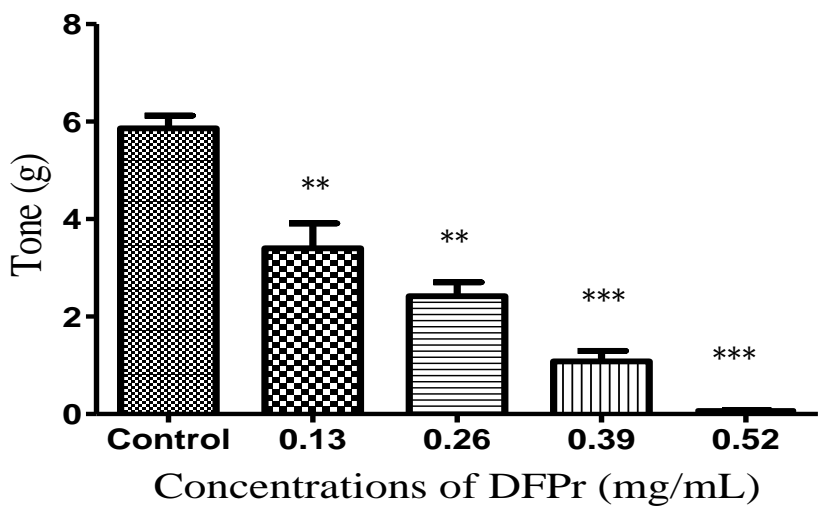

Figure 3 Decrease of tone of intestine contractions induced by ACh

in presence of DFPr $(* * * P<0.001 ; \mathrm{n}=6)$.

DFPr $=$ Dichloromethane fraction of Piliostigma reticulatum

$$
\mathrm{ACh}=\text { Acetylcholine }
$$

\subsection{Antagonism between prazosin (PRAZ) and dichloromethane fraction}

The inhibition of amplitude decrease induced by dichloromethane fraction was correlated by the reduction or the relaxation percentage of the intestine smooth muscle. The percentages relaxation reduction were to $57.8 \pm 1.07 \%$ for $10^{-4} \mathrm{mg} / \mathrm{mL}$ and $18.6 \pm 2.42 \%$ for $10^{-2} \mathrm{mg} / \mathrm{mL}$ of PRAZ (figure 4 ). The reduction of the intestine muscle relaxation induced by the dichloromethane fraction was significant in presence of PRAZ $(p<0,001)$ (figure 5).

A Control

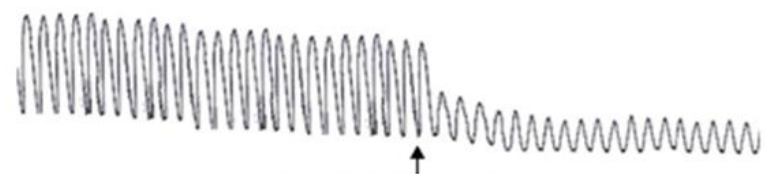

$1 \mathrm{~g}$

$\operatorname{DEPr}(0,24 \mathrm{mg} / \mathrm{mL})$

B

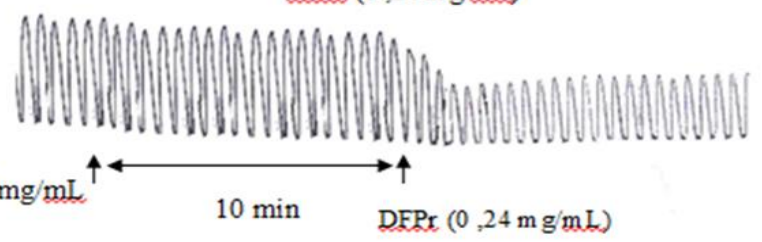

C

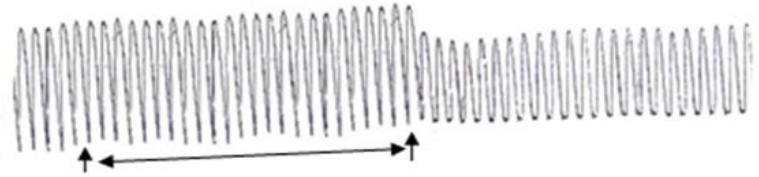

PRAZ $10^{-3} \mathrm{mg} / \mathrm{mL} \quad 10 \mathrm{~min} \quad \operatorname{DFPr}(0,24 \mathrm{mg} / \mathrm{mL})$

D

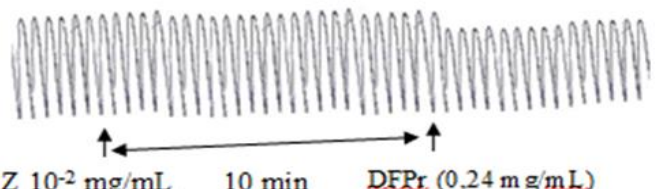

PRAZ $10^{-2} \mathrm{mg} / \mathrm{mL} \quad 10 \mathrm{~min} \quad \operatorname{DERx}(0,24 \mathrm{mg} / \mathrm{mL})$

Figure 4 Interaction PRAZ-DFPr on contractions of isolated rabbit duodenum $(\mathrm{n}=6)$. $\mathrm{DFPr}=$ Dichloromethane fraction of Piliostigma reticulatum $\mathrm{PRAZ}=$ Prazosin 


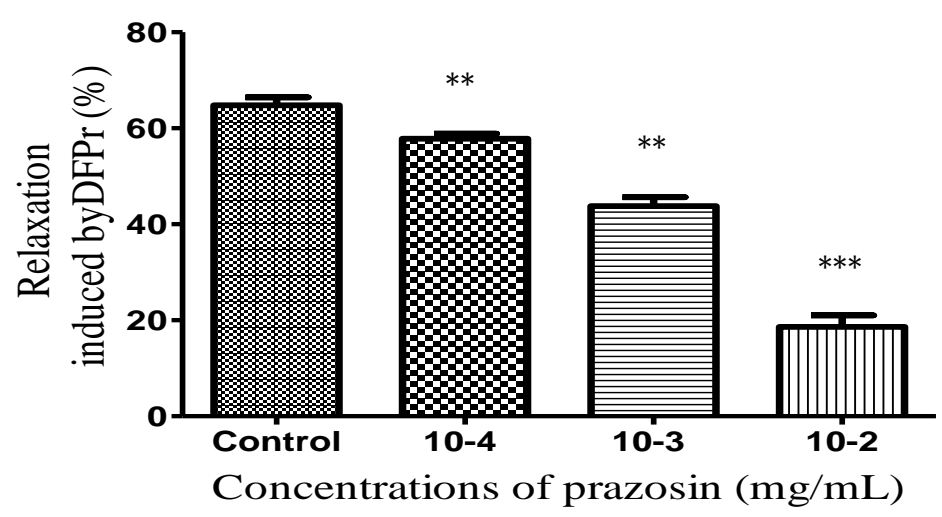

Figure 5 Effect of prazosin on relaxation induced by DFPr

$$
\text { (** } \left.<<0.01 ;{ }^{* * *} \mathrm{P}<0.001 ; \mathrm{n}=6\right) .
$$

DFPr $=$ Dichloromethane fraction of Piliostigma reticulatum

\subsection{Antagonism between propanolol (PROP) and dichloromethane fraction}

The percentages of reduction of contraction amplitude lowered to reach $52 \pm 1.38$; $35.6 \pm 2.01$ and $17.4 \pm 0.7 \%$ for dichloromethane fraction respectively at concentrations of $10^{-4}, 10^{-3}$ and $10^{-2} \mathrm{mg} / \mathrm{mL}$ for PROP (figure 6). The relaxation of the smooth muscle of duodenum was almost totally inhibited at the concentration of $10^{-2} \mathrm{mg} / \mathrm{mL}$ (figure 7). The inhibitions of relaxations were significant $(\mathrm{p}<0,001)$ compared to those induced by the dichloromethane fraction at a dose of $0.24 \mathrm{mg} / \mathrm{mL}$ (figure 7).

A
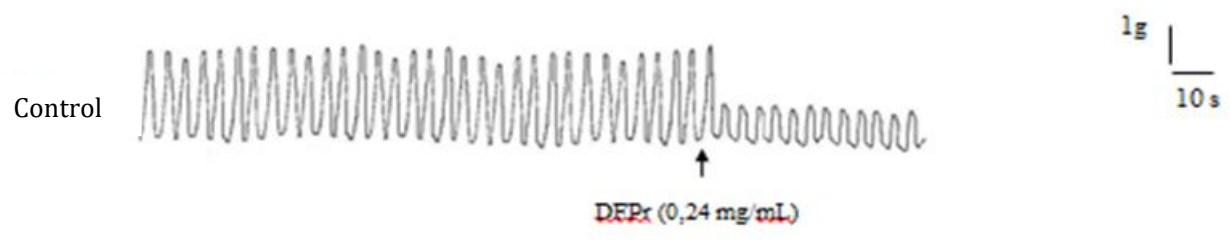

B

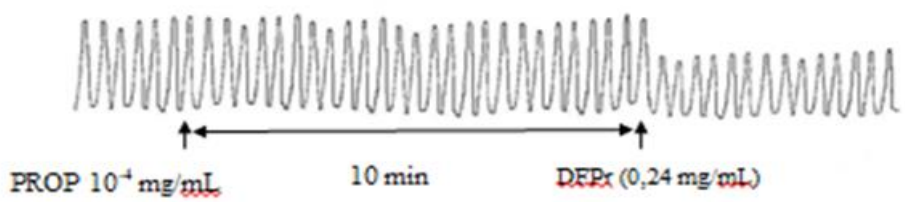

C

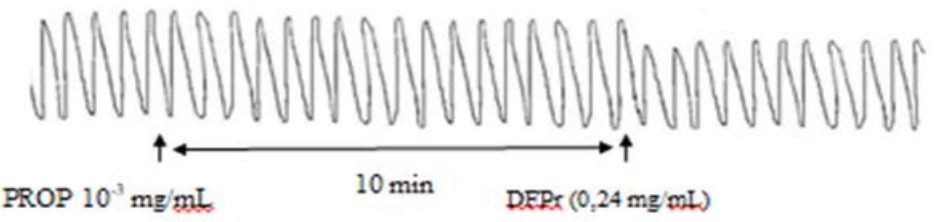

D

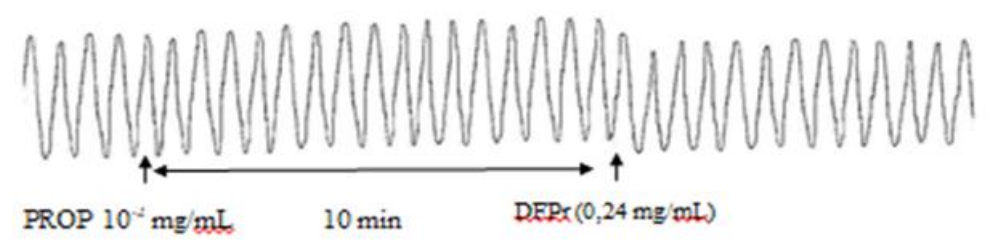

Figure 6 Interaction PROP-DFPr on contractions of isolated rabbit duodenum $(\mathrm{n}=6)$. $\mathrm{DFPr}=$ Dichloromethane fraction of Piliostigma reticulatum $\mathrm{PROP}=$ Propanolol 


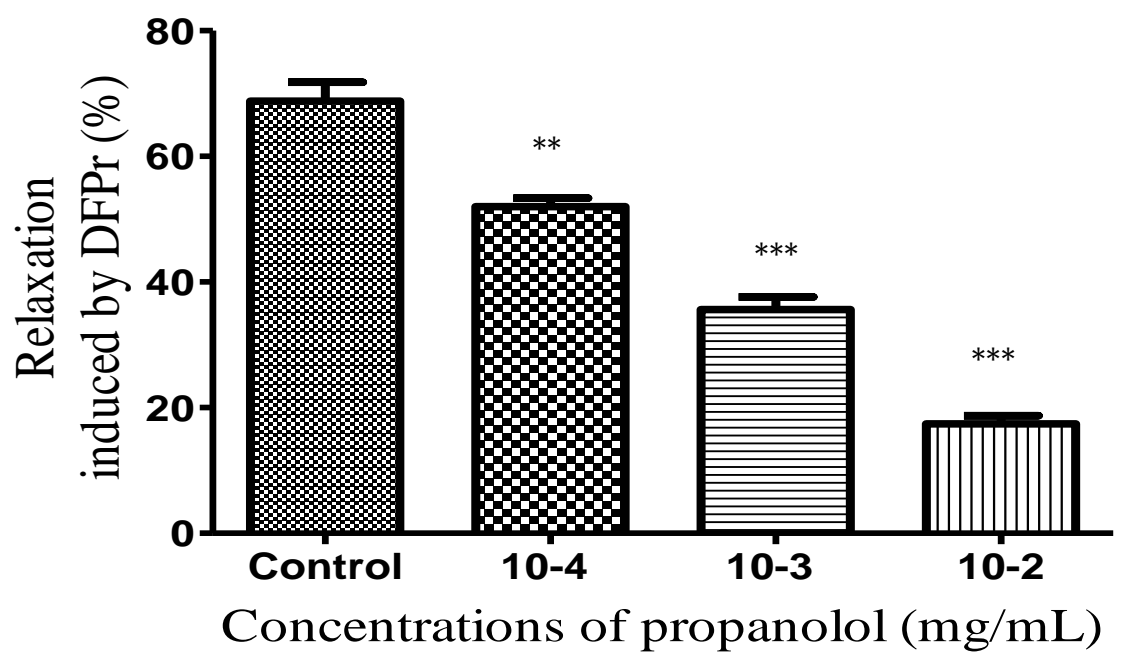

Figure 7 Effect of Propanolol on relaxation induced by DFPr $\left({ }^{* *} \mathrm{p}<0.01 ;{ }^{* * *} \mathrm{P}<0.001 ; \mathrm{n}=6\right)$.

DFPr $=$ Dichloromethane fraction of Piliostigma reticulatum

\subsection{Phytochemical tests}

Phytochemical screening tests revealed the presence of tannins, flavonoïds, polyphenols and reducing sugars. However, Quinones, alkaloids, coumarins, polyterpenes and sterols were not found in dichloromethane fraction (table 1).

Table 1 Phytochemical screening of dichloromethane fraction of stem bark of P. reticulatum

\begin{tabular}{ll}
\hline chemical compounds & Piliostigma reticulatutum \\
\hline Polyphenols & + \\
Sterols et polyterpernes & - \\
Flavonoids & + \\
Saponins & - \\
Tannins & + \\
Alkaloids & - \\
Quinones & - \\
Reducing sugars & + \\
Coumarins & - \\
\hline
\end{tabular}

$(-)$ absence, (+) presence

\section{Discussion}

\subsection{Anticholinergic activity of the dichloromethane fraction}

These studies showed a significant reduction of negative inotrops and positive tonotrops effects induced by acetylcholine on intestine contractions. At a concentration of $0.52 \mathrm{mg} / \mathrm{mL}$, dichloromethane fraction reduced to $11 \pm$ $1.12 \%$, the percentage of amplitude contractions induced by acetylcholine. In addition, the tone induced by acetylcholine was significantly reduced by the dichloromethane fraction. This action of dichloromethane fraction on the effects induced by acetylcholine was dose-dependant. Our results are similar to those obtained by [9]. These authors demonstrated that the essential oil of Monodora mystirica leaves at a dose of $3 \mu \mathrm{g} / \mathrm{mL}$, totally inhibited contractions induced by acetylcholine. Furthermore, the inhibition of contractions induced by acetylcholine with species like Cymbopogon giganteus and Salvadora persica have been studied by [27]. Acetylcholine is a neurotransmitter liberated by parasympathic nervous system which plays a physiological key role in the regulation of intestine movements [30, 31]. Indeed, it is known that the effect of acetylcholine is translated by an increase of membrane permeability to calcium ions or by liberation of intracellular calcium due to the activation of muscarinic receptors of intestine muscle [32, 33]. 
According to the results above, the dichloromethane fraction could contain anticholinergic substances, responsible for the blocking of dichloromethane fraction fixation on muscarinic receptors. Consequently, this prevents the entry of extracellular calcium but the liberation of intracellular calcium. Many authors have shown these anticholinergic effects $[34,35,36]$ with the aqueous leaves extract of Cistus ladaniferus (Cistaceae), the aqueous leaves extract of Carum copticum (Ombelliferous) and the ethanol leaves extract of Helichrysum plicatum (Asteraceae). The inhibition of intestine contractions induced by dichloromethane fraction could be responsible for slowing intestinal transit to inhibit diarrhea.

\subsection{Interaction between dichloromethane fraction and prazosin or propanolol}

These studies showed that the relaxation induced by the dichloromethane fraction is significantly inhibited by propranolol and prazosin. The abolition by propanolol and prasozin for the reduction of the amplitude of rythmic contractions of isolated rabbit duodenum observed with dichloromethane fraction could indicate the existence of adrenomimetic substances in this extract. These substances could operate on duodenum muscles through $\alpha$ and $\beta$ adrenergic receptors, respectively blocked by prazosin and propanolol $[8,28,37]$. In this case we can admit that the dichloromethane fraction could speed up $\alpha$ and $\beta$-adrénergic receptors. According to [38], this activation allows protein Gi ton inhibit the activity of adenylcyclase, provoking a falling of AMPc (Adenosin Monophosphate Cyclic) production. AMPc is not then able to speed up protein kinases which produce phosphate for regulating the cellular membrane proteins of the sarcoplasmic reticulum such as actins and myosins. The absence of phosphorylation provokes the closing of calcium canals, a deactivation of the sarcoplasmic reticulum calcic pomp and a falling of actins and myosins sensitivity for calcium. Thus, rhythmic contractions decrease. The dichloromethane fraction could operate by the same mechanism. Moreover, the dichloromethane fraction could contain adrenomimetic substances, responsible for intestine contractions inhibition.

Flavonoïds, tannins, polyphenols and reducing sugars in dichloromethane fraction could be responsible for the myorelaxant effects observed. Thus, tannins, flavonoïds and reducing sugars are generally responsible for myorelaxant properties of medicinal plants $[39,40]$. Flavonoïds have already shown their ability to inhibit contractions induced by spasmogens [41]. The quercetol, which is a flavonoïd reduces the amplitudes of intestine contractions inhibiting acetylcholine secretion [39]. The anticholinergic and adrenergic effects observed with the dichloromethane fraction could be due to its chemical components.

\section{Conclusion}

The studies of interactions showed that the dichloromethane fraction inhibited intestine contractions induced by acetylcholine. Relaxations induced by dichloromethane fraction were inhibited by propanolol and prasozin, two chemicals blocking the action of adrenaline.

The diarrhea is often caused by a hypercontractility of the intestine; it is therefore probable that medicines that inhibit intestine contractions could be antidiarrheal compounds.

\section{Compliance with ethical standards}

\section{Acknowledgments}

This project was financed in part by a Non-government-organization acting for the promotion of scientific research in African traditional medicine (NGO "PRORESMAT"). The authors are grateful to the National Floristic Centre, University of Felix Houphouet Boigny and to Professor AKE-ASSI Laurent for plant authentication.

\section{Disclosure of conflict of interest}

The authors declare no conflict of interest.

\section{References}

[1] Hasler WL. (2003). Pharmacotherapy for intestinal motor and sensory disorders. Gastroenterology Clinical of North America, 32, 707-732.

[2] Farhadi A, Bruninga K, Fields J and Keshavarzian A. (2001). Irritable bowel syndrome: an update on therapeutic modalities. Expert Opinion Investigation Drugs, 10, 1211-1222. 
[3] Pasricha PJ. (2001). Prokinetic agents, antiemetics and agents used in irritable bowel syndrome. In: Hardman JG, Limbird LE, Goodman Gilman A. (Eds.), Goodman \& Gilman's the Pharmacological Basis of Therapeutics. McGraw Hill, New York, 1021-1036.

[4] Valiollah H, Sadraei H, Ghannadi AR and Mohseni M. (2000). Antispasmodic and anti-diarrhoeal effect of Satureja hortensis L. essential oil. Journal of Ethnopharmacology, 71, 187-192.

[5] Ragone MI, Sella M, Conforti P, Volonté MG and Consolini AE. (2007). The spasmolytic effect of Aloysia citriodora Palace (Souch American cedrón) is partially due to its vitexin but not isovitexin on rat duodenums. Journalof Ethnopharmacology, 133, 258-266.

[6] Borrelli F, Borbone N, Capasso R, Montesanoc D, De Marino S, Aviello G, Aprea G, Masone S and Izzo AA. (2009). Potent relaxant effect of a Celastrus paniculatus extract in the rat and human ileum. Journalof Ethnopharmacology, 122, 434-438.

[7] Corallo MA, Founbge S and Declume C. (1988). Etude expérimentale de l'activité utérotonique de Bridelia atroviridis et Phyllanthus discoideus (Euphorbiacées). Mise en évidence d'un effet au niveau des récepteurs $\alpha$ adrénergiques. Annales Pharmaceutiques Francaises, 46, 171-177.

[8] Koudou J, Aklikok K, Gbeassor M and Bessiere JM. (2001). Composition chimique et activité anticontracturante de l'huile essentielle de Monodora myristica gaertn de la république centrafricaine. Pharmacopée and Medecine Traditionnelle Africaine, 11, 59-67.

[9] Gilani AH, Shah AJ and Yaeesh S. (2007). Presence of cholinergic and calcium antagonist constituents in Saussurea lappa explains its use in constipation and spasm. Phytotherapy Research, 21, 544-1544.

[10] Salawu SO, Tijani AY, Obidike IC and Chindo BA. (2009). Anti-ulcerogenic properties of methanolic root extract of Piliostigma reticulatum (DC) Hoechst (Syn. Bauhinia reticulate DC) -Leguminosae in rats. African Journal of Pharmacy and Pharmacology, 3(5), 252-258.

[11] Arbonier M. (2002). Arbres, Arbustes et Lianes des zones sèches de l'Afrique de l'Ouest. CIRAD, 2nd edn. MNHN, 2574.

[12] Aderogba MA, Okoh EK, Ogundaini AO and Abegaz BM. (2003). C-methylquercetin-3, 3', 4'-trimethyl ether from the leaves extract of Piliostigma reticulatum. Nigerian Journal of Natural products Medicine, 7, 37-8.

[13] Salawu SO, Tijani AY, Obidike IC and Chindo BA. (2007). Evaluation of anti-diarrhoeal properties of methanolic Root extract of Piliostigma reticulatum in rats. Journal of Phytomedicine and Therapeutics, 12.

[14] Yelemou B, Bationo B, Yameogo G and Millogo-Rasolodimby J. (2007). Bois et Forêts des tropiques. ISSN 0006579X, Coden, 291, 55-66.

[15] Dosso K, N'guessan BB, Gnangoran BN and Yapo AP. (2014). Acute toxicity effects of dichloromethane fraction of ethanol extract of stem bark of Piliostigma reticulatum on rats. African Journal of Plant Science, 8(8), 405-409.

[16] Dosso K, N'guessan BB, Bidie AP, Gnangoran BN, Méité S, N'guessan D, Yapo AP and Ehilé EE. (2012). Antidiarrhoeal activity of an ethanol extract of the stem bark of Piliostigma reticulatum (Caesalpiniaceae) in rats. Afrcan Journal of Traditional Complementary and Alternative Medicine, 9(2), 242-249.

[17] Dosso K, N'guessan BB, Amoateng P and Gnangoran BN. (2012). Anti-secretory effects of a dichloromethane fraction of stem bark of Piliostigma reticulatum (Cesalpiniaceae). Journal of Medical and Biomedical Sciences, $1(3), 13-20$.

[18] N'guessan BB, Dosso K, Gnangoran BN, Amoateng B, Asiedu-Gyekye IJ and Yapo AP. (2015). Antibacterial and antispasmodic activities of a dichloromethane fraction of an ethanol extract of stem bark of Piliostigma reticulatum. Journal of Pharmacy and BioAllied Science, 7(2), 128-135.

[19] Kone M, Yao KE, Gbogbo M, N'dri NM and Yapo AP. (2016). Effects of the ethanol extract of Pilistigma reticulatum DC (Horscht) stem bark on biochemical parameters of albino rat wistar. Scholars Academic Journal of Biosciences, 4(1), 11-17.

[20] Harborn JB. (1984). Phytochemical methods. In: A Guide to ModernTechniques of Plant Analysis. Chapman and Hall, 2nd edn, London, 4-7.

[21] Samsam-Shariat SH. (1992). Qualitative and Quantitative Evaluation of the Active Constituents and Control Methods for Medical Plants. Mani Publications, Isfahan (in Persian), 23-30. 
[22] Mitjans M, Garcia L, Marrero E and Vinardell MP. (2008). Study of ligmed-A, an antidiarrheal drug based on liguin, on rat small intestine enzyme activity and morphometry. Journal of Veterinary Pharmacology and Therapeutics, 24, 349-351.

[23] Magnus R. (1904). Persuche am überbunden Dünndarm Yon Saugetieren. Archive of Ges Physiology, 102123.

[24] Perry WLM. (1968). Pharmacological Experiments on Isolated Preparations. E \& S Livingstone Ltd. Edinburgh, 8.

[25] Tona L, Kambu K, Mesia K, Cimanga K, Bruyne T, Pieters L, Totté J and Vlietinck AJ. (1999). Biological screening of traditional preparations from some medicinal plants used as antidiarrhoeal in Kinshasa, Congo. Phytomedicine, 6, 59-66.

[26] Fatou BS, Mamadou S, Doudou D, Modou OK, Abdoulaye B, Bocar S, Lamine G, Aminata SD, Abdoulaye S, Ramaroson A and Fallou C. (2010). In vitro modulation of tracheal smooth muscle reactivity by extracts of some Senegalese medicinal plants. Journal of Medecine Plants Research, 4, 13-18.

[27] Traoré F, Bahi C, Soro YT and Koné PP. (2004). Mise en évidence et caractérisation pharmacologique des principes actifs d'un extrait aqueux de Bridelia ferruginea (Euphorbiaceae). Revue de la Médecine et la Pharmacopée Africaine, 18.

[28] Békro Y, Békro J, Boua BB, Tra Bi F and Ehile EE. (2007). Etude ethnobotanique et screening phytochimique de Caesalpinia benthamiana (Baill.) Herend et Zarrucchi (Caesalpiniaceae). Sciences de la Nature, 4(2), $217-225$.

[29] Gilani A, Shaheen F, Christopoulos A and Mitchelson F. (1997). Interaction of ebeinone, an alkaloid from Fritillaria imperialis, at two muscarinic acetylcholine receptor subtypes. Life Science, 60, 535-544.

[30] Guata Y, Aminata S, Amadou M and Babacar F. (2004). Myorelaxant and antispasmodic effects of the aqueous extract of Mitragyna inermis barks on Wistar rat ileum. Fitoterapia, 75, 447-450.

[31] Bolton TB. (1979). Mechanism of action transmitters and other substances on smooth muscle. Physiology Revue, 59, 607-718.

[32] Mollard P, Mironneau J, Amedee T and Mironneau C. (1984). Action potentiel and Ca2+ inward current in isolated pregnant rat myometrial cell. In "Regulation calcique dans les muscles lisses". Colloque INSERM/CNRS, Editions INSERM, 124, 53-54.

[33] Aziz M, Tab N, Karim A, Mekhfi H, Bnouham M, Ziyyat A and Legssyer A. (2006). Relaxant effect of aqueous extract of Cistus ladaniferus on rodent intestinal contractions. Fitoterapia, 77, 425-428.

[34] Hejazian SH, Morowatisharifabad M and Mahdavi SM. (2007). Relaxant Effect of Carum copticum on intestinal motility in ileum of rat. World Journal of Zoology, 2, 15-18.

[35] Bigovic D, Brankovic S, Kitic D, Radenkovic M, Jankovic T, Savikin K and Zivanovic S. (2010). Relaxant effects of the ethanol extract of Helichrysum plicatum (Asteraceae) on isolated rat ileum contractions. Molecules, 15, 33913401.

[36] Triggle CR. (1985). Adrenergic interactions in smooth muscle contractility. In « Calcium and Contractility ». Ed. By A.K. Grover and E.E. Daniel, The HUMANA press, 37- 60.

[37] Guimaraes S and Moura D. (2001). Vascular adrenoreceptors, an update. Pharmacology Revue, 53, 319-356.

[38] Tripathi K. (1994). Essentials of Medical Pharmacology. Jaypee Brothers, New Delhi, 779.

[39] Venkatesan N, Thiyagarajan V, Narayanan S, Arul A, Raja S, Kumar SGV, Rajarajan T and Perianayagam JB. (2005). Antidiarrheal potential of Asparagus racemous wild root extracts in laboratoire animals. Journal of Pharmacy and Pharmaceutical Sciences, 8, 39.

[40] Capasso F, Pinto A, Mascolo N, Autore G and Franco MP. (1988). Effects of flavonoids on PGE2-and LT4-induced contractions on the guinea pig isolated ileum. Pharmacology Research Commun, 20(1), 201-202.

\section{How to cite this article}

Kassim D, Benoit BN, Dago Serge DA and Angoue Paul YAPO. (2020). Anticholinergic and adrenergic activities of a dichloromethane fraction of a crude ethanol extract of stem bark of Piliostigma reticulatum Horscht D.C (Ceasalpiniaceae). GSC Advanced Research and Reviews, 3(1), 01-10. 